\title{
Gender Features of Discourse in Women's Literature as a Reflection of Changes in the Modern Society
}

\section{Zayneta R. Khachmafova}

Adyghe State University, Republic of Adygea, Russia

Irina S. Karabulatova

Institute of Socio-Political Research of the Russian Academy of Sciences, Moscow, Russia

Svetlana A. Lyausheva

Adyghe State University, 385000, Russian Federation, Republic of Adygea, Maikop, Pervomayskaya, 208

Elena N. Luchinskaya

Kuban State University, Krasnodar, Russia

Email: radogost2000@mail.ru, zaineta@nextmail.ru

\section{Gennady V. Osipov}

\begin{abstract}
Academician of RAS, Doctor of Philosophy, Professor, Director of the Institute of Social and Political Research, Russian Academy of Sciences, 19991 Moscow, Leninsky Prospect 32a,osipov@ispr.ras.ru
\end{abstract}

Doi:10.5901/mjss.2015.v6n3s2p476

\begin{abstract}
The article deals with the problem of new conception of the "female" fiction prose as an independent discourse with special outlook and gender meaningful concepts. The article reveals the meaning of the notion "discourse of the modern female prose" described as complicated sociocultural phenomenon or the reflection of gender-motivated female consciousness revealed in the process of fiction text creation by women-authors. All mentioned features are very important and actual nowadays because the female prose is rapidly developing and represents the certain part of the national worldwide. The fiction texts by the woman-authors are considered to be the female discourse characterized with special outlook and gender-associated language peculiarities and it represents the female language person. The female prose texts undoubtedly reflect new aspects of woman's role and place in the world and also firm stereotypes of man-woman relationships and they created the model for woman the lack of which is felt in modern society.
\end{abstract}

Keywords: gender, fiction text, female style of writing, female prose, gender stratification, gender stereotype.

\section{Introduction}

Gender studies became actual in modern linguistics and they obtained the status of independent linguistic trend (Karabulatova, I.S., 2013). Today the most interesting questions are connected with the investigations of social factors that influence man attitude to women and also people behavior according to their gender. Person's gender is considered to be one of the important existential and social characteristics that determines social, cultural and cognitive person orientation in the world by means of language (Bogolubova, N.M., Nikolaeva J.V., Fokin V.I., Shirin S.S., and Elts E.E., 2013). The investigation of genders role in culture evolution and their symbolic and semiotic expression in philosophy, history, language, literature and art helps to open new aspects of society development and get the deeper understanding of existing processes. The emerging of gender studies and therefore the feminists linguistics in last decades encourages the appearance of the idea of theory necessity of the female literature or female prose, i.e. "female writing". Thus, the language analysis of modern developing female prose is very actual. Undoubtedly the new reading and lingual-stylistic interpretation of the fiction texts written by women-authors make it possible to avoid the traditional literary criticism and 
social-political definitions and analyze the works due to conceptions of «femininity» $и$ «masculinity» that are changing culture notions in historical process. Female fiction literature represents the complicated cultural phenomenon that includes woman-author and woman-reader and also specificity of woman language view.

\section{Methods of Investigation and Research Stuff}

In the process of investigation some scientific methods were used: method of linguistic observation and description of certain language facts for obtaining of generalized data, realized with the help of interpretative method, partially component and contextual analysis were used; method of linguo-stylistic interpretation of fiction text.

Research stuff included the data of theoretical studies in the field of text linguistics, linguo-poetical, cognitive linguistics, gender linguistics, fiction literature stylistics and also the works of the modern female prose in Russian and German languages.

\section{Discussion}

Large-scale appearing of the prose writers-women is caused by the rise of such issues as female freedom and independence in the society and won women rights. It should be mentioned that now the problem of female prose as in general the women status in the modern world has the real interest. It's necessary to underline that due to the feminists scientists the notions "female prose" and "female reading" were introduced to science. In this opinion, woman body and woman sexuality are the main sources of the "female writing" being the form of woman's self-expression. In feminist linguistics the analysis of the concept "Woman" is usually related with the search of gender asymmetries that humiliates female dignity underlining second part and defectiveness of the women that one can meet in patriarch culture. Basic works on feminist critic language belong to Robin Lakoff (Lakoff, R., Language and Woman's Place, 1975) in English language and Luise Pusch (Pusch, L., Das Deutsche als Männersprache, 1984) and Senta Trömel-Plötz (Trömel-Plötz, S., Frauensprache - Sprache der Veränderung, 1982) in German language. The main purpose of such works of the feminists linguistics is to criticize the patriarch mentality and language reform directed for eliminating of defective image of the woman in language and sexist asymmetry existing in speech.

Today the issue about relevancy in considering the "female prose" to be a cultural phenomenon is discussing in modern world that rose the dispute about female creativity, i.e. the ability of women to create mental product of high aesthetic quality on a par with men. One should admit that the notion "female prose" as the very female prose are studied insufficiently in modern linguistics. The problem of female creation caused the contentious debate - from complete negation to unqualified recognition of this cultural phenomenon. Till nowadays the phenomenon of female creativity is impeached, because only the male creative work as a man worldview are considered to be the norm. In literary critical works there is the dominating opinion that "a man is similar to the sky, the horizon, the supreme power, which at the same time ascertains and contains in himself the woman status" (Barthes, R, 1994).

The famous German writer Krista Wolf gives her understanding of the notion "female writing": «lnwieweit gibt es wirklich "weibliches Schreiben"? Insoweit Frauen aus historischen und biologischen Gründen eine andere Wirklichkeit erleben als Männer. Wirklichkeit anders erleben und dies ausdrücken. Insoweit Frauen nicht zu den Herrschenden, sondern zu den beherrschten gehören, jahrhundertelang, zu den Objekten der Objekte. Objekte zweiten Grades, oft genug Objekte von Männer, die selbst Objekte sind, also, ihr er sozialen Lage nach, unbedingt Angehörige der zweiten Kultur; insoweit sie aufhören, sich an dem Versuch abzuarbeiten, sich in die herrschenden Warnsysteme zu integrieren» (Forster, H., Deutsche Literaturgeschichte, 1999). - «In what case one can speak about the existence of "female writing"? Only as the women due to the historical and biological reasons differently precept the outside world. They differently endure the reality and express it in other way. Being in the possession the women are the object of objects, i.e. the objects of the second degree and men's objects, who are the objects themselves. Thus, by their social statute the women certainly belong to the second culture because they stop their hard effort for integrating into ruling mad system».

In her article «To the question of feminist poetics» Elein Showalter studies three main types of writing in female literature (Showalter, E., 1985):

- Representation of "feminine" that expresses in imitation of the canons of predominant /patriarch literary tradition and internalization of the formed gender standards of art and the social roles.

- Representation of "feminist" connected with the expression of the protest against predominant /patriarch standards and culture and language values, the defense of minority rights and values including the demand of woman's autonomy.

- Representation of "female" as a specific woman's identity differed from the male canon of representation and 
writing (Showalter, E., 1985).

The right question is if we can study gender in the text and in what way. Undoubtedly the gender of the reader and the gender of the author impact the process of creation and perception of the literary text. The most interesting question in the feminists literary criticism theories concerns the outer, i.e. formal differences between the woman-author text and man-author text. Many scientists reject the opportunity of determination of the author's gender in the fiction text. The gender theory gives us a new way of interpretation of the fiction works by analyzing of the means of presentation male or female worldview, i.e the specific of the language view of the man and the woman. In the given study the fiction texts written by the man-authors are not considered at all and moreover the comparative analysis of the man and woman texts is not carried out. We proceed from the main principle of modern gender studies which claims that the authorship cannot be gender neutral category. The accent is put upon the investigation of female fiction texts for revealing genderassociated and gender-motivated peculiarities of the female language worldview. So, we don't touch any evaluative categories of the tradition ("male") literary work with respect to female one.

In the article "Gender and literature: the problem of "female writing" and "female reading"» Mary Rutkenen notes, that if "some features of the texts are determined as "feminine" this fact cannot help us find the woman in the texts. "Feminine features" can be noted in the men's texts. But the study of strategies used by the women becomes very important for the context and the subjects of female literature and drawing the attention to the female gender».

It's necessary to underline, that understanding of the femininity is impossible without such social feature as stratification. Gender stratification is a process during which gender becomes the basis of the social stratification. Actually in every society due to social characteristics there are two gender types and that's why one biological sex has got social role that are considered to be culturally secondary. Femininity as a rule is related to the "female" and means decreasing the social and cultural status and so traditionally perceived as culturally secondary phenomenon. At the same time «feminine» according to the tradition is beyond the norm. That is stereotypical understanding of the femininity is connected with the gender inequality. Gender inequality as a social construct emerged on the base of natural biological distinction between men and women. Social norms and roles constantly change through the times however gender asymmetry remains unchangeable.

For the purpose of our study and defining of such notions as "language of the female texts" or "female fiction text" and "female style of writing" we need to investigate the thematic and contextual strategies of the woman-author. It's seems very important to study the female subject if we rise a question on what ways and models of writing are used by the women and why. In that way it's possible to take into consideration woman experience (the author and the reader) and consider its influence on textual strategies.

There are the coincident points between the periods of woman emancipation and the processes of foundation of the female prose phenomenon. In their fiction texts the female writers open the new world of the woman and it described by the woman-author, who suggest not only the new themes but new behavior samples to the society and defend the woman right for self-independent choice and independent fortune. It's necessary to stress that emerging of the women writing the fiction works with the woman as the main heroine who builds her own life initiated the appearance of the female prose phenomenon.

Certainly, the appearance of the female prose phenomenon demanded the definite social and cultural situation: the situation of mass-cultured society with all features of production, reproduction and consumption of mass literature. Female prose is the phenomenon of mass literature that realizes legitimization of marginal woman experience through the self-identity practices.

To define female prose means taking into account the fact that it's related to literature and to the woman status in the society.

The evident preference of private to common and individual to social is specific feature in female prose. The global problem of female texts at the same time narrows down to the scope of a certain family, private fate and widen in global perspective of people's relationships. The element that unites local and global, private and common, individual and mankind is happiness. In the centre of the fiction texts there is often a woman - mother, wife, lover, rival: alone, sacrificial, strong, unhappy. The woman-author writes about the women because she knows them much better than the men. The texts of modern female prose are characterized by the metaphorical images, fusion of irony and lyrics, sometimes hard irony and everyday definiteness of the types correlated with the real life. In the plot of female narration there are everyday family events near the woman. Thus, the main themes of such texts are family, husband, children, home, love, sacrifice, human relationships and woman career and so on. Woman's fate is important for the modern woman-writers, that's why in the centre of the fiction work there is She (Woman). The heroins of female prose are wise, sympathetic to the close people (child, man, friend, mother, colleague, etc.), she can forgive and love. Striving for higher destination to be mother is showed in her textual space. Woman's awareness of the mysterious world happens from 
involving in his mysteries: conception, pregnancy, delivery, therefore - unique types of the heroines and revealing of the woman's view of the world. It's the woman who can fully transmit the depth of the feelings and emotional experience. Undoubtedly, all this differs the woman worldview from the man one.

In the process of studying of the fiction texts of the female prose written in Russian and German languages we marked possible archetypes of heroines: wife, mother, lover, friend, rival, strong woman, unhappy woman, unloved woman, abandoned woman, single woman, lone mother, etc.

Short stories that can provide differences in communication ways caused by gender factor are the best material for gender distinctions. Analysis of female prose texts proved that gender distinctions are represented in various language levels. The most interesting facts were found through comparing Russian and German linguocultures. The study of motivation of choice of the grammar, lexical and stylistic language means depend on gender. Thus, gender is presented as the product of the culture and social relations and it realizes in language.

Gender stratification of modern female prose discourse is understood as realization of gender distinctions in female fiction texts in verbal means that are showed in language:

1) in verbal-semiotic language level;

2) in the sphere of cognitive phenomenon represented with notions, concepts, ideas, stereotypes that form gender worldview which reflects values system;

3) in pragmatical level that includes aims, reasons, interests, purposes and intentions.

In this way elucidation of sex roles in culture development and their symbolic and semiotic representation in philosophy, history, language, literature and art allow to show the new aspects of society development and to understand the current processes deeper. New texts interpretation allows to avoid the traditional literature criticism and sociopolitical definitions and analyze fiction texts due to presentation of such notions as feminine and masculine that are culture constructs which change in history. Gender "measurement" gives differ look at well-known facts or works and helps to interpret them due to gender differentiation, deconstruct seemingly firm notions and reveal subtexts representing the symbols of woman experience.

Investigation of the specificity of modern female prose discourse supposes the description of the actual gender worldview fragment; the conflict between the heroine and the hero is placed in the centre of it and depicted by means of the following gender roles realized in: a) love affairs; b) family life; $c$ ) in the professional sphere.

Gender specificity of the modern female prose is represented in the following character features:

there is a woman or female subject in the core of the plot (the narration is held from the 1st person, the genre of «female autobiography»), for example: «l waited for the whole life. From seventeen years old. Every day. Had married and waited. Born the child and waited» (V. Tokareva. Neither son, neither wife, nor brother); «lch habe es nicht aufgegeben, mich von meinem Glück zu überzeugen. Ich bin hartnäckig gewesen» (Mechtel, $A$. Katrin, 1993);

- depiction of private everyday life of common people and particularly women (family, home, children, parents, friends, "love triangle", betrayal, jealousy, etc.), for example: «She has uncommonly unhappy love affair and for this reason she abandoned her first unintelligible husband; she had many problems with the object of her love, then she gave birth to Grishka and though she seldom went out with her lover during thirteen years she delayed the moment of meeting her son and his real mysterious father» (L. Ulitskaya. Queen of Spades); «Ich war wie gemacht dafür, Mutter zu werden, war ich doch ein ganzer Mensch. Man sagt ja, eine Schwangerschaft erfordert einen ganzen Menschen» (Jelinek, E. Paula, 1987);

family and congenial relations become more important that other types of social relations in female prose, for example: «Only few manage to find a core which helps them to avoid this. And rest upon it all their life. It is usually a family. Home, wife, children, a dog. PC, mother-in-law, sport channel» (O. Robsky. Casual/Everyday); «Ich habe inm gesagt, dass ich ihn liebe. Ich habe Zärtlichkeit gelernt; habe die Kinder in Schutz genommen, wenn er wütend war; habe gelernt, dass er wütend sein durfte. Ich habe es mir erklären können. Ich bin nicht verzweifelt. Ich habe mir gesagt, dass ich glücklich bin» (Mechtel, A. Katrin, 1993); regarding the subject of home violence (wife - husband) and discrimination in professional sphere (employee employer), for example: «Es ist ein großes Glück, wenn man sich Mutter werden fühlt, ich aber fühlte nur die Schläge meines Gatten auf meinen nun ungeschmeidigen und daher zu wenig wendigen Leib herniederhageln» (Jelinek, E. Paula, 1987);

the relations with opposite sex reveal in comprehension of personal «l» as one of the most important reasons of existential essence of feminine, for example: «No wonder in Biblical legend it was the woman who chose the forbidden fruit - who pays that chooses. That who chooses he cries. It is the confining woman pays for uprighting and large brain. The sufferings in childbirth are given for the equality to the Gods» by N. Sukhanova. 
Delos; «Und ich merke, dass ich allein bin, dass ich niemanden befreien kann und auch nicht den Mut habe, mich gegen die Ungerechtigkeit aufzulehnen. Und ich weine, warte auf jemanden, der mich versteht, der tröstend seinen Arm um mich legt, und habe gleichzeitig Angst, jemand konnte erkennen, dass ich in Wirklichkeit gar nicht stark bin» (Anders R., Was ich fühle, 1990);

in contrary to the men literary tradition the woman experience is represented mainly in physical, biological terms, etc., for example: «And Margosha felt how the bud is blossoming out inside the belly and it rushes to Emka and she melted from enjoyment and touched Emka's breast firstly with her lips and then tenderly with fingers near the nipple...» (L. Ulitskaya. Women in Russian villages); «lhre Gefühle, ihre Gedanken sprangen aus dem gewohnten Gleis, rasten ohne Bahn ins Freie. Sie ließ ihren Gefühlen und Gedanken freien Lauf» (I. Bachmann. Ein Schritt nach Gomorrha).

The reader of the female prose can easily catch the communicative purpose and the problem set by the author with the help of the titles. The title is considered to be the special figurative sign that is important for the main text idea decoding which represent author's modality, for example: «Everybody has ordinary children» by V. Solovyova, «One shot for courage» by V. Tokareva, «CASUAL/Everyday» by O. Robsky, «Woman logic» by I. Polyanskaya, «Ducky» by L. Ulitskaya, «Mom, live well!» by L. Mironikhina, «Happiness» by S. Vasilenko, «Housewife» by N. Nabatnikova, «Kin and close» by N. Molovtseva, «My favourite» by T. Tolstaya, «Was ich fühle» by R. Anders, «Ein netter Kerl» by G. Wohmann, «Ein Strafmandat der Liebe» by H. Clausens, «Meine alleinstehenden Freundinnen» by H. Schubert, «Das heutige Weibliche» by D. Dahn, «Familienidylle» by Ch. Nöstlinger, «Eine Frau wie Sie» by H. Doutine, «Haus, Frauen, Sex» by M. Schreiner (Shirin, S.S., 2015).

Cognitive structures of the female language person form dominant topics or typical situations so called themes of the modern female discourse, they are the following:

- feminine culture;

- motherhood and children upbringing;

- family / home, etc.;

- domestic labour;

- woman discrimination;

- woman education;

- occupation / career;

- woman health.

- The detailed image of the woman differentiated due to the age, status, social functions, behaviour types and occupations is created in the female prose discourse. After all in textual space one can see such woman type that is differentiated in semantic areas by various subsistences according to attitude to the man: wife, lover, mother, widow, etc. Women and their character are defined according to the relation to a men and realize through the opposition «self-sustainability - dependency». The woman often becomes the object of the action and the subject of consumption. Positive woman characteristics relate to the sphere of man's necessity.

\section{Conclusion}

All mentioned features are very important and actual nowadays because the female prose is rapidly developing and represents the certain part of the national worldwide. The fiction texts by the woman-authors are considered to be the female discourse characterized with special outlook and gender-associated language peculiarities and it represents the female language person. The female prose texts undoubtedly reflect new aspects of woman's role and place in the world and also firm stereotypes of man-woman relationships and they created the model for woman the lack of which is felt in modern society.

\section{References}

Barthes, R., 1994. Selected works. Semiotics. Poetics: Translated from French language/ Comp, ed., introduction G.K.Kosikov / R.Barthes. M.: Progress. 616 pp.

Forster, H., 1999. Deutsche Literaturgeschichte. Die Gegenwart 1968-1990 / H. Forster, P. Riegel. München. Bd. 12,378 pp.

Lakoff, R., 1973. Language and Women's Place / R. Lakoff // Language in Society. N 2. 45-79 pp.

Pusch Luise, F., 1984. Das Deutsche als Männersprache. Aufsatze und Glossen zur feministischen Linguistik / Luise F. Pusch. Frankfurt a. M.: Suhrkamp. 202 pp.

Showalter, E. Towards a Feminist Poetics / E. Showalter // The New Feminist Criticism. Essays on Women, Literature and Theory / ed. by E. Showalter. N. Y.: Pantheon Books. 
Trömel-Plötz, S. 1982. Frauensprache - Sprache der Veränderung / S. Trömel-Plötz // Frankfurt a. M.: Fischer Taschenbuch Verlag. 218 pp.

Mechtel, A. Katrin, 1993. Themen und Strukturen. Grundband Deutsch für die Oberstufe / hrsg. von H. Biermann, B. Schurf. Berlin: Cornelsen Verlag. 22-24 pp.

Anders, R., 1990. Was ich fühle / R. Anders // Geschichten / hrsg. von K.H. Spinner. - Frankfurt am M.: Verlag Moritz Diesterweg. 6-7 pp.

Jelinek, E. Paula, 1987. Nirgends ein Ort. Deutschsprachige Kurzprosa seit 1968 / hrsg. von A. Hartmann, R. Leroy. - München: Hueber. 57-66 pp.

Victoria, Tokarev. Neither the son nor his wife, nor his brother//Storybook. M.http:// http://libok.net/writer/2044/kniga/55590/tokareva_ viktoriya_samoylovna/ni_syinu_ni_jene_ni_bratu/read

Mechtel, A. Katrin, 1989. Deutsche Kürzgeschichten II. 11.-13. Schuljahr / Günther Lange (Hrsg.). Stuttgart: Philipp Reclam jun. $23-26$ pp.

Ulitskaya, L. Queen of Spades. http://webreading.ru/prose_/prose_contemporary/lyudmila-ulickaya-pikovaya-dama-i-drugie.html

Robski, O. Casual. Повседневное. М., 2009. 220 c.

Ulitskaya, L. Women of Russian villages. http://www.libtxt.ru/ulitskaya_lyudmila/28303-zhenshchini_russkih_seleniy.html Ingeborg, Bachmann. Stories. Step towards Gomorrah. http://lib.mn/blog/ingeborg_bahman/

Shirin, S.S., 2015. Corruption in higher education in Russia - First decade of the 21st century. International Education Studies, 8 (2), 160-168 pp.

Bogolubova, N.M., Nikolaeva J.V., Fokin V.I., Shirin S.S., and Elts E.E., 2013. Contemporary problems of cultural cooperation: Issues in theory and practice (2013) Middle East Journal of Scientific Research, 16 (12), pp. 1731-1734. http://www.scopus.com/inward/ record. url?eid=2-s2.0-84.

Karabulatova, I.S., 2013. The Problems of Linguistic Modeling of New Eurasian Linguistic Personality in Multilinguistic and Mental Environment (By Example of Onomasphere)// Middle-East Journal of Scientific Research 17 (6): 791-795, 2013.ISSN 19909233.๑ IDOSI Publications. DOI: 10.5829/idosi.mejsr.2013.17.06.12262. 